\title{
METAFORA KONSEPTUAL TEKS BERITA PILGUBSU PADA HARIAN WASPADA DAN ANALISA
}

\author{
${ }^{1}$ Muhammad Surip, ${ }^{2}$ T. Silvana Sinar \\ ${ }^{1,2}$ Program Pascasarjana Linguistik USU \\ ${ }^{1,2}$ Fakultas Ilmu Budaya Universitas Sumatera Utara \\ e-mail: ${ }^{1}$ surif@unimed.ac.id \& ${ }^{2}$ tengkusilvana@usu.ac.id
}

\begin{abstract}
Abstrak
Tujuan penelitian ini adalah mengungkapkan data metafora yang dipusatkan pada penggunaan metafora dalam teks berita PILGUBSU pada harian Waspada dan Analisa dengan menggunakan analisis metafora konseptual. Sumber daya yang digunakan adalah teks berita yang terbit selama bulan Maret 2018. Data penelitian berupa satuan lingual, baik leksikal maupun gramatikal yang mengandung metafora. Untuk menjelaskan data, digunakan kerangka teori linguistik kognitif. Metode pengumpulan data mengambil inspirasi dari metaphor identification procesure dari Pragglejaz group, sedangkan metode pengolahan data dilakukan secara analisis konseptual berdasarkan dua ranah yakni ranah sumber dan ranah sasaran. Metode analisis yang digunakan adalah metode referensial, yang digunakan untuk menunjukkan dan membandingkan referen atau makna yang terdapat dalam sumber dan target ungkapan metaforis yang dianalisis. Hasil penelitian metafora konseptual teks berita Pilgubsu pada harian waspada dan analisa yaitu : ranah politik, makhluk hidup, benda mati, aktivitas manusia, fenomena alam, gaib dan ruang dan waktu.
\end{abstract}

Kata kunci : Metafora Konseptual, Teks Berita PILGUBSU

\section{A. PEndahuluan}

Pemilihan Gubernur Sumatera Utara (PILGUBSU) merupakan salah satu upaya secara demokrasi rakyat dalam memilih Gubernur dan Wakil Gubernur yang akan memimpin Provinsi Sumatera Utara pada periode 2018-2023 mendatang. PILGUBSU akan digelar pada 27 Juli 2018 bersamaan dengan pemilihan 171 kepala daerah di Indonesia. Sedangkan masa kampaye calon Gubernur Sumatera Utara dimulai pada 15 Februari sampai 23 Juni 2018. Selama masa kampaye berlangsung, tentu isi teks berita terkat PILGUBSU di media massa sarat perang urat saraf. Setiap hari berita tentang kegiatan calon menghiasi media massa yang ada.

Dalam menulis sebuah berita, para jurnalis tak luput dari berbagai faktor yang melingkupinya, seperti idealitas dan kontruksi diri, kepentingan lembaga dan kepentingan kandidat calon. Hal tersebut dapat mempengaruhi jurnalis hingga menghasilkan berita yang dipublikasikan dalam bentuk media cetak. Selain itu, para jurnalis juga menggunakan bahasa 
kiasan atau yang lebih umum sering disebut gaya bahasa atau majas untuk membuat tulisannya lebih menarik untuk dibaca. Gaya bahasa adalah bahasa indah yang dipergunakan untuk meningkatkan efek dengan jalan memperkenalkan serta memperbandingkan suatu benda atau hal tertentu dengan atau hal lain yang lebih umum (Tarigan, 1985: 5).

Metafora banyak dipakai dalam sebuah teks berita guna menyampaikan informasi kepada pembaca, tidak hanya berita Pilgubsu saja. Laksana mengatakan bahwa penggunaan majas metafora pada berita lebih produktif dibandingkan penggunaan majas lainnya. Ia memberikan tiga alasan mengapa metafora lebih banyak digunakan, yaitu: Metafora lebih disukai oleh wartawan dan editor yang menulis tajuk berita dibandingkan dengan majas lainnya; (2) Metafora potensial untuk memenuhi kebutuhan wartawan dan editor akan penggunaan kata yang baru; (3) Metafora lebih menarik daripada jenis majas lain. (Laksana. 1994: 129).

Selain tiga hal di atas, penggunaan metafora didukung pula oleh pentingnya pembaca mengetahui berita yang dituliskan dengan sudut pandang jurnalis dan perbandingan yang lain, dan tentunya menggunakan bahasa jurnalis yang dapat mengiaskan bahasa dalam bentuk metafora. Begitu juga yang terjadi dengan fenomena berita tentang Pilgubsu yang saat ini sedang masa kampanye oleh masing-masing calon gubernur Sumatera Utara. Teks berita surat kabar juga tidak lepas dari unsur-unsur metaforis pada setiap wacana berita yang disajikan. Kecenderungan penggunaan metafora yang cukup produktif dalam menulis wacana berita, bagi seorang wartawan, dapat digunakan sebagai cara pengungkapan yang lebih spesifik, yang dapat dijadikan ciri khas, dan yang membedakan mereka dengan jurnalis lain.

Selain itu, metafora juga dapat menimbulkan efek keindahan bukan hanya bagi para jurnalis tetapi juga bagi khalayak pembaca karena banyak menggunakan kosa kata dengan kombinasi yang selalu baru. Dengan itu, penggunaan metafora dalam teks berita bertujuan untuk memberikan perspektif yang agak berbeda terhadap suatu topik berita kepada para pembaca tentu saja dengan cara pengungkapan yang lebih menarik.

Namun demikian, penggunaan metafora pada teks berita bukan berarti tidak menimbulkan efek negatif terutama jika merujuk pada bahasa surat kabar yang lebih spesifik dan apabila penggunaannya secara berlebihan serta tidak proporsional. Bahasa yang digunakan dalam teks berita seharusnya mengikuti kaidah-kaidah bahasa jurnalistik yang sederhana, jelas, dan mudah dipahami karena surat kabar akan dibaca oleh berbagai kalangan masyarakat yang tentu saja dengan latar belakang variasi kemampuan berbeda-beda. Teks berita surat kabar juga seharusnya menggunakan kalimat-kalimat singkat dan hemat kata-kata karena berkaitan dengan ruang penyajian (lay out) surat kabar yang memang terbatas. Penggunaan metafora 
secara tidak proporsional berpotensi menimbulkan ambiguitas penafsiran terutama bagi khalayak pembaca dengan latar belakang pendidikan yang tidak memadai karena menggunakan pilihan kata dengan kombinasi baru dan secara semantik merujuk pada hal lain di luar makna leksikalnya.

Saat ini, berita tentang Pilgubsu sangat sensitif, karena salah satu tahapan pemilu yakni masa kampanye sedang berlangsung dan tentunya masing-masing kandidat tanpa kenal waktu untuk terjun kepada masyarakat dalam meyakinkan untuk memilih saat pencoblosan berlangsung nanti. Masing-masing kandidat pastinya menggunakan berbagai media dalam mensosialisasikan program-program kerja janji politiknya kepada masyarakat Sumatera Utara. Tanpa terkecuali, juga menggunakan media cetak dalam menyampaikan program unggulan dan aktivitas kampanye kepada masyarakat. Tidak pun permintaan calon dan tim kampanye untuk memberitakan aktivitas calon Gubsu dalam kampanye. Media massa yang ada pastinya akan mengemas aktivitas tersebut dalam berita, karena informasi Pilgubsu sedang hangat di sampaikan melalui berita di media cetak.

Setiap kalimat yang di dalamnya mengandung kata bermakna kias atau gaya bahasa memiliki makna yang berbeda-beda. Di dalam kata tersebut mengandung makna atau arti yang berbeda tergantung leksem yang terdapat pada kalimat tersebut. "Pembedahan" makna secara linguistik terhadap kata yang mengandung majas dianggap perlu agar dapat diketahui apa makna atau arti dari kata tersebut. Atas dasar itu, penelitian ini akan di fokuskan pada melihat penggunaan metafora dalam teks berita surat kabar dari sisi metafora konseptual. Sehingga pembaca berita tidak hanya membaca teks berita saja namun harus memahami makna dibalik konsep teks berita yang disampaikan.

Beberapa penelitian terkait metafora teks berita dalam media cetak telah dilakukan oleh beberapa peneliti sebelumnya antara lain oleh Gallini (1997) yang mengungkapkan pengaruh metafora dalam pemrosesan teks berita dan hubungannya dengan informasi baru. Herlinda (2009) dalam penelitiannya mengangkat analisis pemakaian gaya metafora yang terpadat pada media masa cetak dengan menggunakan term e-135. Andriani (2013) juga meneliti tentang analisis penggunaan metafora pada berita olahraga dalam surat kabar yang memunculkan makna kata yang bukan sebenarnya, sehingga diharapkan dapat dijadikan materi pembelajaran kebahasaan (2013). Begitu juga Tarwiyah (2016) yang mengangkat analisis ekspresi metafora yang digunakan dalam persaingan berita di media online. Sekaligus juga mengangkat jenisjenis ekspresi metafora yang digunakan dan alasan di balik penggunaan ekspresi tersebut. Budiman (2017) dalam penelitiannya juga mengungkapkan penggunaan metafora dalam teks 
berita yang difokuskan pada tiga aspek yakni : aspek konseptual, kebahasaan dan kontekstual kewacanaan.

Berdasarkan uraian di atas, peran media cetak, khususnya surat kabar sangatlah penting bagi masyarakat. Media cetak yang digunakan sebagai objek dalam tulisan ini adalah berita terkait pemilihan gubernur Sumatera Utara dalam harian Waspada dan Analisa. Surat kabar Waspada dan Analisa dinilai dinikmati oleh semua masyarakat Sumatera Utara karena kedua media tersebut merupakan media dengan oplah terbanyak, bahkan media tersebut sudah termasuk kategori media nasional. Tulisan ini berupaya mengulas metafora konseptual dalam teks berita Pilgubsu di harian Waspada dan Analisa yang dipakai dalam pembentukan ungkapan atau istilah tertentu dengan memanfaatkan metafora konseptual. Atas dasar hal ini, penelitian ini menarik dilakukan karena media sering menggunakan metafora dalam menyampaikan informasi kepada masyarakat. Sedangkan masing-masing data teks berita yang berbentuk metafora menarik untuk diteliti, karena pembaca harus lebih jeli dalam menafsirkan isi berita yang ada. Sehingga penelitian ini diupayakan dapat mengangkat makna dibalik metafora tersebut.

\section{B. KAJIAN TEORI}

\section{Metafora}

Secara etimologis, kata metafora berasal dari meta yang berarti setengah atau tidak sepenuhnya seperti pada kata metafisika (setengah fisik, yang berhubungan dengan bendabenda nonfisik, atau tidak sepenuhnya fisik) dan fora (phora) yang artinya memuat, merujuk atau mengacu. Berdasarkan makna kata tersebut, menurut Saragih (2006:29), metafora merujuk sesuatu yang tidak sepenuhnya lagi atau hanya setengah merujuk sesuatu dalam memahami atau menyampaikan pengalaman dalam ranah atau bidang lain. Definisi yang kurang lebih sama seperti yang disusun oleh Duranti (dalam Saragih, 2006:136) bahwa metafora adalah memahami atau merealisasikan pengalaman dalam satu bidang berdasarkan atau merujuk pada bidang lain.

Tarigan (1985:15), mengatakan bahwa metafora adalah salah satu gaya bahasa perbandingan yang paling singkat, padat, dan tersusun rapi. Menurut Djayasudarama (1999:22), gaya bahasa kiasan atau metafor ialah perbandingan yang implisit. Jadi, tanpa kata seperti atau sebagai di antara dua hal yang berbeda misalnya, sumber ilmu, buah hati, mata jarum, anak emas. Chaer (dalam Pateda, 2001:234), mengatakan bahwa metafora dapat dilihat dari segi digunakannya sesuatu untuk membandingkan yang lain dengan yang lain. Oleh Kridalaksana (2001:136), metafora (metaphor) dikatakan sebagai pemakaian kata atau 
ungkapan lain untuk objek atau konsep lain berdasarkan kias atau persamaan misalnya, kaki gunung, kaki meja, berdasarkan kias pada kaki manusia.

Badudu (dalam Pateda:2001:36), mengatakan struktur dasar metafora sangat sederhana yaitu, sesuatu yang dibicarakan dan ada sesuatu yang dipakai sebagai perbandingan sehingga, dapat dikatakan bahwa gaya bahasa metafora adalah gaya bahasa yang membandingkan suatu benda dengan benda lain. Selanjutnya, rumusan umum yang disampaikan oleh Ogden dan Richards (dalam Pateda:2001), mengatakan metafora secara umum berfungsi sebagai penunjuk sekelompok benda yang saling berhubungan satu dengan lainnya dan bertujuan sebagai penghubung dalam hubungan analogis antar kelompok yang berbeda.

\section{Metafora Konseptual}

Teori metafora yang dijadikan dasar analisis data dalam tulisan ini adalah teori metafora yang diprakarsai Lakoff dan Johnson (2003:3) yang menyatakan bahwa metafora merefleksikan apa yang kita alami, kita rasakan, dan apa yang kita pikirkan dalam kehidupan sehari-hari. Seperti yang dikatakan Black dan ditegaskan oleh Ungerer dan Schmid (1996:118), metafora bertindak sebagai alat kognitif. Pendapat itu didukung pula oleh Saeed (2003:342), bahwa bahasa itu merupakan daerah mental dan kemampuan linguistik didukung oleh bentuk pengetahuan khusus. Metafora bukan hanya sebagai alat untuk menyatakan ide melalui bahasa, melainkan sebagai alat untuk memikirkan sesuatu. Hal ini didukung Lakoff dan Johnson (dalam Ungerer dan Schmid, 1996:118), bahwa kita tidak hanya menggunakan metafora +time is money, secara linguistik, tetapi kita memikirkannya atau mengkonseptualisasikannya, sehingga dapat diibaratkan time sebagai target dan money sebagai sumber, yang dipikirkan sebagai komoditi yang berharga dan sumber yang terbatas. Dengan cara pandang seperti itu, maka muncullah ungkapan metaforis seperti "you're wasting my time", "can you give me a few minutes", "how do you spend your time?".

Contoh lainnya yakni bahasa yang digunakan merupakan bukti secara sistematis cara manusia mengkonseptualisasikan apa yang dipikirkan, dialami, dan apa yang dilakukan. Dengan kata lain, bahasa menunjukkan bagaimana manusia mengkonstruksikan idenya. Lakoff dan Johnson (2003:4) menunjukkan suatu metafora bahwa argument tis war. Metafora itu diformulasikan dari bahasa sehari-hari berdasarkan yang dilakukan dan dialami dalam berargumentasi, misalnya "I demolished his argument", "I've never won an argument with him", "He shot down all of my arguments".

Kalimat-kalimat di atas mengandung ungkapan-ungkapan yang mengkonstruksikan bahwa argumen adalah perang. Formulasi bahwa argumen adalah perang dibangun dari apa 
yang dilakukan ketika berdebat atau berargumentasi. Ketika berargumentasi manusia melakukan seperti sedang berperang, sehingga digunakan kata menyerang argumen atau pendapat, mempertahankan ide, merobohkan argumen, mengalahkan, menggunakan strategi untuk menyapu semua, dan seterusnya; dan itu terjadi ketika perang. Apa yang dilakukan dalam perang adalah mempertahankan negara, menyerang musuh, mengalahkan musuh, dan seterusnya.

Kaitannya dengan contoh yang diberikan, Lakoff dan Johnson (2003:5) menegaskan bahwa konsep itu secara metaforis terstruktur, aktivitas yang dilakukan juga terstruktur, dengan demikian, bahasa yang digunakan juga terstruktur, dan metafora yang digunakan dalam mengkonseptualisasikan seperti yang dijelaskan sebelumnya dinamakan metafora konseptual. Metafora konseptual bersifat dinamis, karena metafora itu memanifestasikan apa yang sedang dipikirkan, dirasakan, dan dilakukan penggunanya yang selalu berubah sesuai dengan pikiran, perasaan, dan pengalaman berbeda di setiap budaya.

Selain metafora struktural, ada metafora orientasional (orientational metaphor), dan metafora ontologis (ontological metaphor). Metafora orientasional (Lakoff dan Johnson, 2003:14) “...organizes a whole system of concepts with respect to one another". Metafora ini berkaitan dengan orientasi ruang, yaitu atas-bawah, dalam-luar, depan-belakang, ada-tidak ada (on-off), dalam-dangkal, tengah-pinggir. Mereka mencontohkan bahwa happy is up. Kenyataan bahwa ketika senang atau bahagia, seseorang berada dalam kondisi semangat. Metafora orientasional merefleksikan konsep spasial yang berbeda-beda menurut pengalaman fisik atau budaya masyarakatnya (Lakoff dan Johnson, 2003: 14). Oleh karena itu, metafora orientasional berbeda di setiap budaya, karena apa yang dipikirkan, dialami, dilakukan orang di setiap budaya berbeda, sehingga yang dikonseptualisasikan juga berbeda dan membawa pengaruh pada sistem konsep yang diwujudkan dalam metafora juga berbeda. Metafora ontologis memiliki bermacam-macam tujuan, sehingga bermacam-macam jenis yang ada merefleksikan tujuan yang dimaksud (Lakoff dan Johnson, 2003:25-26).

\section{Komponen Metafora Konseptual}

Konvecses (2006: 116-126) menyatakan bahwa metafora konseptual merefleksikan apa yang dipersepsikan, dialami, dan dipikirkan orang tentang kenyataan dunia. Semua yang dialami, dipersepsikan, dan dipikirkan merasuk dalam memori semantik yang dapat digunakan kapan saja. Untuk dapat menggunakannya, seseorang kemudian mengaktifkan memori itu untuk direalisasikan dalam bentuk verbal yang digunakan dalam berbahasa. Sehingga ungkapan-ungkapan metaforis kadang lebih dipilih dibandingkan dengan ungkapan yang tidak 
metaforis karena ungkapan metaforis mengandung muatan yang diutamakan, diperhatikan, dan emosi yang ada dalam ungkapan sesuai dengan yang diinginkan pengguna ungkapan.

Metafora memiliki dua komponen, yaitu: target dan sumber. Berdasarkan penjelasan Lakoff dan Johnson (1980; 2003) yang diperkuat oleh Kovecses (2006), target biasanya lebih abstrak, dan sumber lebih konkret. Untuk dapat memahami maksud yang terkandung dalam metafora ditemukan kesamaan karakteristik yang dimiliki antara target dan sumber. Dengan membandingkan karakteristik yang dimiliki keduanya, akan ditemukan dasar suatu metafora digunakan.

Pemilihan suatu sumber tertentu untuk suatu target dilakukan karena didasarkan pada pengalaman yang dirasakan tubuh ketika mengalami kondisi yang dirasakan. Misalnya, dicontohkan oleh Kovecses (2006:117) + affection is warmth+ itu didasarkan pada pengalaman ketika mendapatkan kasih sayang dari orang lain, seseorang merasakan hangat, sehingga muncul metafora itu.

Seperti yang telah dijelaskan sebelumnya bahwa metafora konseptual mengindikasikan suatu proses yang ada dalam ranah untuk menjelaskan suatu entitas yang didasarkan pada perasaan, pengalaman, dan pikiran tentang realitas yang benar-benar ada atau yang dibayangkan ada, dengan menggunakan entitas lain yang lebih konkret atau dapat divisualisasikan atau dirasakan oleh tubuh.

Oleh karena itu, menurut Kovecses (2006:128) ada komponen-komponen yang dapat dijelaskan sebagai berikut. 1) ranah sumber, ranah target, dan dasar metafora. Ketiga komponen ini merupakan komponen dasar dalam metafora konseptual. Ranah sumber yang memiliki ciri lebih konkret merupakan dasar untuk menjelaskan target yang bersifat lebih abstrak. Misalnya, dalam metafora +life is a journey+, dapat dipahami bagaimana kehidupan (life) yang bersifat abstrak itu digambarkan sehingga lebih mudah untuk dipahami karena dibandingkan dengan perjalanan (journey). Orang dapat mengerti apa yang dimaksud dengan kehidupan (life) yang menjadi target berdasarkan kesamaan ciri yang dimiliki oleh perjalanan (journey) sebagai sumber. Kesamaan ciri atau karakteristik yang ada dalam kedua komponen itu menjadi dasar metafora, misalnya kalau dalam perjalanan ada tujuan, rintangan, jarak yang ditempuh, dan dalam kehidupan ada kesulitan hidup, kemajuan hidup, tujuan hidup, dan seterusnya.

Teori metafora konseptual Lakoff dan Johnson akan digunakan untuk menentukan klasifikasi metafora dan asal ranah sumber dari kata/frasa metaforis yang terdapat dalam lirik lagu dangdut. Metafora konseptual melihat keterhubungan antara kedua ranah, yaitu ranah sumber dan ranah sasaran ke dalam bentuk pemetaan atau korespondensi. Ranah sumber 
digunakan untuk konsep area di mana metafora digambarkan, sedangkan ranah sasaran digunakan untuk konsep area di mana metafora diaplikasikan (Knowles dan Moon, 2006: 33).

Menurut Lakoff dan Johnson (Cruse, 2004: 201), metafora konseptual dianalisis sebagai proses konseptualisasi kognitif bergantung pada tiga hal, yaitu (1) ranah sumber (source domain), (2) ranah sasaran (target domain), dan (3) pemetaan atau korespondensi (a set of mapping relation or correspondences). Korespondensi dalam metafora menurut Lakoff dan Johnson (Cruse, 2004: 201) terdiri atas dua kategori, yaitu: (1) korespondensi ontologis mengacu pada sifat dasar dari hubungan dua entitas, dan (2) korespondensi epistemis mengacu pada pengetahuan pada pengetahuan kita yang menghubungkan kedua entitas tersebut.

Menurut Lakoff dan Johnson, terdapat dua konsep, yaitu abstrak dan konkret. Konsep abstrak dibangun secara sistematis dari konsep konkret melalui proses metaforis. Lakoff dan Johnson menamai konsep abstrak tersebut conceptual metaphor, yang didefinisikan sebagai generalized metaphorical formulas that characterize specific abstraction. Jadi, yang disebut metafora konseptual adalah abstraksi tertentu yang diwujudkan dalam metafora-metafora yang digeneralisasi.

\section{Teks Berita Media Surat Kabar}

Surat kabar merupakan salah satu bentuk produk media cetak di antara beragamnya produk industri media massa. Media massa sendiri diklasifikasikan menjadi tiga kelompok, yakni (1) media cetak; sepeti majalah, tabloid, dan surat kabar atau koran; (2) media eletronik; misalnya radio dan televisi; dan (3) media online atau lebih dikenal sebagai media sosial. Surat kabar adalah media cetak yang terbit harian atau setiap hari baik pagi maupun sore.

Sedangkan struktur teks berita surat kabar, seperti diuraikan oleh Badara (2013:37), yakni: (1) piramida terbalik; struktur piramida terbalik sebagai berikut: kalimat (1) berisi inti/topik berita, satu tema dan satu pengertian; kalimat (2) berisi hal-hal yang sangat dekat hubungannya dengan kalimat 1; kalimat (3) mendukung kalimat 2; kalimat (4) mendukung kalimat 3; kalimat (5) berisi hal-hal lain yang relevan terhadap isi berita.

Umumnya berita yang berstruktur piramida terbalik adalah berita yang memiliki nilai berita tinggi dan stop press. (2) piramida; berita dengan struktur piramida diawali dengan yang kurang penting, menuju ke yang paling penting. (3) kronologis; penyajian berita tidak didasarkan pada hal yang penting atau kurang penting karena setiap kalimat yang dituangkan relatif memiliki bobot yang sama.

Bahasa yang digunakan dalam berita surat kabar disebut dengan bahasa jurnalistik (language of mass communication) yang oleh M. Romli (dalam Badara: 2013:12) dirumuskan, 
sebagai berikut: (1) jelas dan mudah dipahami, (2) sederhana, (3) hemat kata, (4) menghindari penggunaan kata mubazir dan kata jenuh, (5) singkat, (6) dinamis dan tidak monoton, (7) penulisan kalimat lead dan isi tetap menaati kaidah bahasa, (8) satu gagasan satu kalimat.

\section{METODE PENELITIAN}

Penyediaan data dilakukan dengan metode simak bebas libat cakap (nonparticipant observation), dan dilanjutkan dengan teknik catat. Selain itu, metode intuisi juga digunakan sebagai pendamping penyediaan data. Menurut Deignan (2005:110), metode intuitif sering digunakan para peneliti metafora konseptual, seperti Lakoff dan Johnson, Kovecses, yaitu dengan menggunakan pengalaman peneliti yang telah menginternalisasi di dalam diri peneliti. Sampelnya adalah ungkapan-ungkapan metaforis yang terdapat dalam teks berita Pilgubsu di harian Waspada dan Analisa.

Adapun metode analisis yang digunakan adalah metode referensial, yang digunakan untuk menunjukkan dan membandingkan referen atau makna yang terdapat dalam sumber dan target ungkapan metaforis yang dianalisis. Selain itu, content analysis dengan teknik inferensi juga digunakan untuk menunjukkan bagaimana proses kognitif terjadi dalam menghasilkan ungkapan metaforis untuk menghubungkan antara sumber dan target, dan menemukan dasar metafora yang menentukan hubungan sumber dan target. Metode pengumpulan data mengambil inspirasi dari metaphor identification procesure dari Pragglejaz group, sedangkan metode pengolahan data dilakukan secara analisis konseptual.

\section{HASIL DAN PEMBAHASAN}

Berdasarkan hasil kajian analisis data terdapat 40 data metafora konseptual dalam teks berita pemilihan Gubernur Sumatera Utara dalam harian Waspada dan Analisa terbitan Maret 2018. Berikut penjelasan dan pembahasan data penelitiannya.

\section{Pengidentifikasian Metafora Konseptual Teks Berita}

Berdasarkan klasifikasi metafora tersebut, teridentifikasi 40 data yang diperoleh dari teks berita yang ada di terbitan Harian Waspada dan Analisa. Keempat puluh data metafora tersebut dapat dilihat pada data di bawah ini :

a) Metafora dalam ranah politik yang terwujud dalam kata-kata : politik uang dan politisasi SARA, peta politik, politik blusukan, Pilgubsu berjalan secara sehat, selimut kerakusan, partai medsos, politik dinasti, perang secara sehat dan memancing emosi, suhu politik. 
b) Metafora dalam ranah makhluk hidup diwujudkan dalam kata-kata : ladang garapan orang asing, kuda hitam, kuda tunggangan, terbangkan ekonomi.

c) Metafora dalam ranah benda mati terlihat dalam kata-kata : kendaraan masuk surga, mendongkrak popularitas, jubah kamuflase, cermin buruk, kerikil-kerikil yang mewarnai perjalanan, segenggang emar umat, dan mesin partai.

d) Metafora dalam ranah aktivitas manusia terwujud dalam kata-kata : JR-ANCE main lagi, memancing kegaduhan, ringan tangan, petarung sejati, Sumatera Utara pintar dan sehat.

e) Metafora dalam ranah fenomena alam tergambar dalam kata-kata : banjir dukungan, kota hijau dan lokomotif pembangunan.

f) Metafora dalam ranah gaib dapat tergambar dalam kata-kata : di atas manusia masih ada Tuhan, rumah bertuah, menghipnostik rakyat, dan surga hasil pemberian Tuhan.

g) Metafora dalam ranah ruang dan waktu dapat dilihat pada kata-kata : wadah kembangkan kreativitas, berjalan semu, heboh dahulu-senyap kemudian, perekat umat, membius rakyat, merangkul semua rakyat, perang secara santun dan bangun masyarakat Sumut menjadi manusia cemerlang.

\section{Pemetaan Konseptual Metafora dalam Teks Berita}

Hasil identifikasi sebelumnya secara sekilas menunjukkan adanya konseptualisasi konsep-konsep lain kepada konsep metafora teks berita. Lakoff dan Johnson berpendapat untuk dapat menjelaskan metafora konseptual diperlukan analisis pemetaan konseptual. Pemetaan konseptual akan dapat lebih menjelaskan sistem konsep-konsep yang terwujud dari klasifikasi metafora teks berita yang telah ada dalam data.

Hasil dari pengidentifikasian metafora teks berita ini selanjutnya perwujudannya akan dijabarkan dalam konsep-konsep yang dipetakan dalam antar ranah.

a) Metafora Teks Berita dalam Ranah Politik

(1) Calon Gubsu diimbau agar tidak melakukan politik uang dan politisasi SARA (Analisa, 1/3)

(2) Masuknya kembali JR Saragih kebursa kandidat Gubsu sudah pasti mengubah peta politik (Waspada, 5/3)

(3) Politik blusukan menjadi langkah bagi kedua calon dalam menggaet hati rakyat (Analisa, 5/3)

(4) Proses Pilgubsu harus berjalan secara sehat dan aman (Analisa, 5/3)

(5) Mereka tertidur pulas dalam selimut kerakusan politik (Waspada, 7/3) 
(6) Calon Gubernur Rock N Roll dari partai medsos (Analisa, 10/3)

(7) Kita bersyukur bahwa di Sumut belum pernah ada politik dinasti, tidak seperti beberapa daerah lain yang kena tangkap KPK (Waspada, 31/3)

(8) Kita harus perang secara sehat dengan lawan politik, tidak perlu memancing emosi tim pemenangan dan warga (Waspada, 31/3)

(9) Suhu politik Pilgubsu semakin menghangat dan panas (Analisa, 31/3)

Tabel 1 Pemetaan konseptual metafora teks berita dalam ranah politik

\begin{tabular}{ll}
\hline \multicolumn{3}{c}{ Sasaran } & \multicolumn{1}{c}{ Sumber } \\
\hline $\begin{array}{l}\text { usaha meraih kekuasaan dengan cara } \\
\text { menggunakan uang atau SARA untuk }\end{array}$ & \\
mempengaruhi pemilih agar memilihnya & \\
\hline mengubah arah kesepakatan politik & peta politik \\
\hline $\begin{array}{l}\text { usaha mempengaruhi sikap dan pendirian } \\
\text { pemilih lewat terjun langsung kemasyarakat }\end{array}$ & \\
bawah & \\
\hline $\begin{array}{l}\text { proses Pilgubsu berjalan sesuai aturan yang } \\
\text { ada tanpa ada gangguan yang menghambat }\end{array}$ & Pilgubsu berjalan secara sehat \\
\hline $\begin{array}{l}\text { pemimpin atau penguasa yang sesuka hati } \\
\text { menggunakan kelimut kerakusan politik } \\
\text { kepentingan diri dan keluarga }\end{array}$ & \\
\hline $\begin{array}{l}\text { partai politik yang dominan menggunakan } \\
\text { media sosial dalam berpolitik kepada } \\
\text { masyarakat }\end{array}$ & \\
\hline $\begin{array}{l}\text { upaya merebut kekuasaan secara bergantian } \\
\text { dengan saudara kandung }\end{array}$ & politik dinasti \\
\hline $\begin{array}{l}\text { berpolitik secara benar dengan menjunjung } \\
\text { tinggi aturan yang berlaku }\end{array}$ & perang secara sehat \\
\hline $\begin{array}{l}\text { situasi dan kondisi politik sedang aktif di } \\
\text { perbincangkan oleh masyarakat }\end{array}$ & panu politik sedang hangat dan \\
\hline
\end{tabular}

b) Metafora Teks Berita dalam Ranah Makhluk Hidup

(10) Jangan lagi potensi laut SUMUT jadi ladang garapan orang asing (Waspada, 1/3)

(11) JR Saragih bisa jadi kuda hitam bagi pasangan lainnya (Waspada, 5/3)

(12) Politik hanya dijadikan kuda tunggangan untuk menghancurkan masa depan rakyat, bukan menjadi karpet merah untuk melayani rakyat (Waspada, 9/3)

(13) Ada 148 koperasi di masyarakat terlihat mati suri, oleh karena itu jika kami terpilih akan kita terbangkan ekonomi Sumut (Analisa, 21/3) 
Tabel 2 Pemetaan konseptual metafora teks berita dalam ranah makhluk hidup

menjadi wilayah tangkapan ikan orang ladang garapan orang lain asing, padahal nelayan dalam negeri

kesulitan mendapatkan ikan

pasangan alternatif yang bisa menang tanpa kuda hitam

diprediksi publik

politik dijadikan jalan atau media untuk kuda tunggangan dan karpet merah

merebut kekuasaan tanpa mementingkan

kesejahteraan rakyat dan berupaya

komitmen melayani rakyat

memajukan ekonomi dengan terbangkan ekonimi

memberdayakan ekonomi kerakyatan

c) Metafora Teks Berita dalam Ranah Benda Mati

(14) Ilmu harus menjadi kendaraan untuk masuk surga (Waspada, 2/3)

(15) Mendongkrak popularitas calon Gubsu dengan tampilan kesederhanaan (Waspada, $3 / 3)$

(16) Demokrasi hanya jadi jubah kamuflase dalam merebut kekuasaan (Analisa, 8/3)

(17) Kasus korupsi telah menjadi cermin buruk bagi kandidat Pilgubsu (Analisa, 10/3)

(18) Kerikil-kerikil yang mewarnai perjalanan JR-ANCE untuk menjadi salah satu kontestan di Pilgunsu 2018akan menimbulkan asumsi liar apakah JR-ANCE ingin maju atau tidak (Waspada, 15/3)

(19) Nasib madrasah yang dibangun dari segenggam emas umat ini harus kita kembangkan menjadi maju (Waspada, 22/3)

(20) Mesin partai menjelang Pilgubsu harus jalan dan tetap bersinergi (Analisa, 23/3)

Tabel 3 Pemetaan konseptual metafora teks berita dalam ranah benda mati Sasaran Sumber

\begin{tabular}{ll}
\hline usaha meraih jalan menuju surga & kendaraan masuk surga \\
\hline mengangkat popularitas calon pemimpin & mendongkrak popularitas \\
\hline demokrasi dijadikan media untuk merebut & jubah kamuflase \\
kekuasaan & \\
\hline $\begin{array}{l}\text { kasus korupsi harus menjadi pelajaran bagi para } \\
\text { kandidat Cagubsu }\end{array}$ & \\
\hline
\end{tabular}


berbagai permasalahan dan kendala telah menjadi kerikil-kerikil mewarnai pencalonan penghambat pencalonanan JR Saragih dan ANCE

upaya kerja keras rakyat dalam membangun segenggam emas

madrasah

seluruh elemen partai harus ambil bagian dalam mesin partai

pemenangan calon

d) Metafora Teks Berita dalam Ranah Aktivitas Manusia

(21) JR. Saragih dan Ance main lagi dalam kompetisi Pilgubsu (Waspada, 4/3)

(22) Kita jangan sampai memancing kegaduhan ditengah-tengah masyarakat (Analisa, $11 / 3)$

(23) Ijeck dikenal rakyat Sumut sebagai tokoh muda yang ringan tangan (Analisa, 27/3)

(24) Sangat disayangkan JR-ANCE gagal ikut Pilgubsu, padahal beliau dikenal warga sebagai petarung sejati (Analisa, 29/3)

(25) Salah satu program Cagubsu Djarot-Sihar akan canangkan program Sumut pintar dan sehat (Analisa,31/3)

Tabel 4 Pemetaan konseptual metafora teks berita dalam ranah aktivitas manusia

Sasaran Sumber

pasangan JR Saragih-Ance dapat berkompetisi JR Saragih dan Ance main lagi lagi dalam Pilgubsu

tim kampanye jangan sampai membuat memancing kegaduhan

perselisihan di tengah masyarakat yang membuat

perpecahan

calon merupakan panutan rakyat yang sering tokoh yang ringan tangan

memberikan bantuan

kandidat yang siap berkompetisi secara terbuka petarung sejati

program Sumatera Utara yang dapat mendorong Sumut pintar dan sehat rakyatnya untuk pintar dan sehat 
e) Metafora Teks Berita dalam Ranah Fenomena Alam

(26) Sudah berbuat untuk Padanglawas, Edi Rahmayadi banjir dukungan rakyat (Waspada, $14 / 3)$

(27) Mari selamatkan bumi SUMUT dengan kembangkan kota hijau (Analisa, 22/3)

(28) Potensi alam Sumut merupakan lokomitif pembangunan menuju kemajuan (Waspada, $30 / 3)$

Tabel 5 Pemetaan konseptual metafora teks berita dalam ranah fenomena alam

Sasaran

Sumber

\begin{tabular}{l}
\hline dukungan rakyat terus mengalir secara terus banjir dukungan rakyat \\
menerus bagai air mengalir ketempat yang lebih \\
rendah \\
mengembangkan kota yang penuh pepohonan kembangkan kota hijau \\
yang rindang \\
jalan menuju pembangunan yang dapat lokomotif pembangunan \\
mensejahterakan rakyat
\end{tabular}

f) Metafora Teks Berita dalam Ranah Alam Gaib

(29) Di atas manusia masih ada Tuhan yang Maha Kuasa (Analisa, 1/3)

(30) Rumah yang ditempati Cagubsu Jarot ini bertuah bagi kami saat Pilgubsu periode yang lalu (Waspada, 3/3)

(31) Kekuasaan akan menghipnostik rakyat miskin (Waspada, 7/3)

(32) Kita bertekad agar surga hasil pemberitan Tuhan untuk masyarakat Sumut yang sejahtera (Waspada, 27/3)

Tabel 6 Pemetaan konseptual metafora teks berita dalam ranah alam gaib

Sasaran Sumber

\begin{tabular}{ll}
\hline $\begin{array}{l}\text { Tuhan Maha Kuasa dari kekuasaan yang dimiliki } \\
\text { oleh manusia }\end{array}$ & di atas manusia masih ada Tuhan \\
\hline tempat bermukim yang penuh kebaikan & rumah bertuah \\
\hline
\end{tabular}


kekuasaan yang dimiliki manusia dapat kekuasaan akan menghipnostik rakyat mengubah cara pandang dan prilaku rakyat

kekayaan potensi alam Sumut merupakan surga hasil pemberian Tuhan pemberian Tuhan untuk kemaslahatan rakyat

g) Metafora Teks Berita dalam Ranah Ruanga dan Waktu

(33) Butuh wadah kembangkan kreativitas anak muda SUMUT (Waspada, 6/3)

(34) Kemenangan dalam Pilgubsu biasanya akan berjalan semu dan berujung (Analisa, $15 / 3)$

(35) Pelaksanaan Pilgubsu heboh dahulu, senyap kemudian (Waspada, 19/3)

(36) IMM diharapkan jadi perekat umat menjadi jembatan untuk tidak Golput (Waspada, 20/3)

(37) Melalui pesta Pilgubsu dapat membius rakyat untuk bersatu dan jangan memecah belah umat (Waspada, 24/3)

(38) Siapapun yang terpilih nanti, Gubsu yang baru harus mampu merangkul semua rakyat Sumut (Analisa, 24/3)

(39) Djarot ingin perang secara santun untuk Sumut yang bermartabat (Waspada, 26/3)

(40) Kita akan bangun masyarakat Sumut menjadi manusia cemerlang dan sejahtera (Analisa, 28/3)

Tabel 7 Pemetaan konseptual metafora teks berita dalam ranah ruang dan waktu

Sasaran Sumber

tempat atau sanggar untuk mengembangkan wadah kembangkan kreativitas kreativitas para pemuda

setelah calon terpilih sebagai gubernur dan wakil berjalan semu dan berujung

gubernur, biasanya berjalan normatif sesuai

agenda yang ada

saat kampanye hebohnya luar biasa, namun saat Pilgubsu heboh dahulu senyap

sudah terpilih realisasi janji-janjinya lambat kemudian

diwujudkan 
pendorong umat untuk tidak golput saat jembatan untuk tidak golput pemilihan

kegiatan pilgubsu dapat mempengaruhi rakyat membius rakyat untuk bersatu untuk bersatu dan tidak memecah belah umat

gubernur terpilih harus mampu menggandeng merangkul semua rakyat semua rakyat untuk mendukung segala kebijakan

jalani pemilu sesuai aturan dengan adu gagasan perang secara santun untuk kemaslahatan rakyat

rakyat yang bahagian dan punya masa depan manusia cemerlang

\section{E. SIMPULAN}

Simpulan yang dapat ditarik dari penjelasan di atas adalah proses pembentukan metafora konseptual yang terjadi dalam menghasilkan ungkapan metaforis yakni dengan mengonseptualisasikan kesamaan sifat, ciri, dan kekuatan yang dimiliki sumber dengan yang dimiliki target, dengan tujuan untuk menggambarkan kejadian atau pengalaman yang dialami, dirasakan, dan dipikirkan oleh penulis berita tentang segala yang terjadi di masyarakat. Strategi yang digunakan untuk mengonseptualisasikan adalah dengan strategi asosiatif, yaitu: strategi untuk menghidupkan memori semantiknya yang berkaitan dengan sifat, ciri, maupun kekuatan yang dimiliki sumber untuk dibandingkan dengan target. Hasil penelitian metafora konseptual teks berita Pilgubsu pada harian waspada dan analisa yaitu : 1) ranah politik (politik uang dan politisasi SARA, peta politik, politik blusukan, Pilgubsu berjalan secara sehat, selimut kerakusan, partai medsos, politik dinasti, perang secara sehat dan memancing emosi, suhu politik), 2) ranah makhluk hidup (ladang garapan orang asing, kuda hitam, kuda tunggangan, terbangkan ekonomi), 3) ranah benda mati (kendaraan masuk surga, mendongkrak popularitas, jubah kamuflase, cermin buruk, kerikil-kerikil yang mewarnai perjalanan, segenggang emar umat, dan mesin partai), 4) ranah aktivitas manusia (JR-ANCE main lagi, memancing kegaduhan, ringan tangan, petarung sejati, Sumatera Utara pintar dan sehat), 5) ranah fenomena alam (banjir dukungan, kota hijau dan lokomotif pembangunan, 6) ranah alam gaib (di atas manusia masih ada Tuhan, rumah bertuah, menghipnostik rakyat, dan surga hasil pemberian Tuhan), dan 7) ranah ruang dan waktu (wadah kembangkan kreativitas, berjalan semu, heboh dahulu-senyap kemudian, perekat umat, membius rakyat, merangkul semua rakyat, perang secara santun dan bangun masyarakat Sumut menjadi manusia cemerlang). 


\section{F. SARAN}

Penelitian selanjutnya diharapkan dapat melihat dari berbagai persepektif dalam teks berita. Selain itu yang dikaji dapat lebih luas cakupannya bukan hanya berita politik.

\section{DAFTAR PUSTAKA}

Chomsky, Noam. 1972. Language and Mind. New York: Cambridge University Press.

Deignan, Alice. 2005. Metaphor and Corpus Linguisitcs. Amsterdam: John Benjamins Publishing Company.

Djawanae, Stephanus. 2009. Telaah Bahasa, Telaah Manusia. Pidato Pengukuhan Jabatan Guru Besar dalam Ilmu Linguistik pada Fakultas Ilmu Budaya Universitas Gadjah Mada, tidak diterbitkan. Fakultas Ilmu Budaya UGM Yogyakarta.

Jay, Timothy B. 2003. The Psychology of Language. New Jersey: Prentice Hall. Jorgensen, Marianne dan Phillips

Louise. 2002. Discourse Analysis as Theory and Method. London: SAGE Publications. Kess, Joseph F. 1992. Psycholinguistics: Psychology, Linguistics, and the Study of Natural Language. Amsterdam: John Benjamins Publishing Company. Knowles, Murray dan Moon

Rosamund. 2006. Introducing Metaphor. London: Routledge.

Kovecses, Zoltan. 2006. Language, Mind, and Culture. Oxford: Oxford University Press.

Lakoff, George dan Johnson, Mark (2003). Metaphors We Live By. Chicago dan London: The University of Chicago Press.

Lakoff, George. 2006. Conceptual Metaphor: The Contemporary Theory of Metaphor. Edited by Dirk Geeraerts. Cognitive Linguistics: Basic Reasings. Berlin: Walter de Gruyter.

Nirmala, Deli dan Chandra, Oktiva Herry. 2009. Representasi Persepsi dan Sikap Masyarakat Semarang terhadap Layanan Publik Melalui Metafora dalam Surat Pembaca Harian Nasional. (Laporan Penelitian tidak Diterbitkan, yang dibiayai DIPA Fakultas Ilmu Budaya Oktober 2009).

Saeed, John I. 2003. Semantics. Second Edition. Oxford: Blackwell Publishing.

Searle, John. 1977. Speech Acts: An Essay in the Philosophy of Language. London: Cambridge University Press. Metaphor. Dalam Andtrew Ortony. ed. 1979. Metaphor and Thought. Cambridge: Cambridge University Press.

Sudaryanto. 1993. Metode dan Aneka Teknik Analisis Bahasa. Pengantar Penelitian Wahana Kebudayaan secara Linguistis. Yogyakarta: Duta Wacana University Press. 
Ungerer, F dan Schmid, H.J. 1996. An Introduction to Cognitive Linguistics. London: Longman.

Ortony, Andrew .(ed). 1993. Metaphor and Thought. Cambridge: Cambridge University Press.

Paivio, Allan. 1979. Psychological Processes in the Comprehension of Metaphor. Edited by Andrew Ortony dalam Metaphor and Thought. Cambridge: Cambridge University Press. Stern

Josef. 2000. Metaphor in Context. Cambridge: The MIT Press. 